\title{
Cirios, trompetas y altares. El auto de fe como fiesta
}

\author{
DORIS MORENO MARTINEZ*
}

\section{RESUMEN}

El análisis del auto de fe en su vertiente festiva nos permite superar la vieja polémica de la historiografía liberal y la historiografía conservadora,

en torno a la popularidad/repulsión social de la Inquisición. Trascendiendo

las visiones unidireccionales, se intenta aprender el auto de fe general desde una perspectiva global; se integran las vertientes juridica, religiosa y social a través de algunos de los múltiples ingredientes del auto:

sensitivos (luz, colores, sonidos...), sociales (participación activa de artesanos, familiares y asistentes...) y simbólicos lorden preeminencial en las procesiones y en los tablados, juramentos...), para configurar el auto de fe como una fiesta compleja. poliédrica. En el auto de fe la Iglesia y el Estado tantas veces enfrentados, mostraban sus respectivos poderes concertados, con toda la capacidad

\section{ABSTRACT}

The analysis of the auto de fe on its festive side allows us to overcome the old discussion between the liberal historical view and the conservative view that surrounds the social popularity/repulsion of the Inquisition. Overcoming the narrow vision we try to understand a global perspective; we integrate the juridical, religious and social aspects through some of the many ingredients of the auto de fe: sensory (light, colours, sounds...), social (active participation of artisans. families and people present...) and symbolical (order of rank in processions on stages and oath taking...). All those aspects combine to make the auto de fe a very complex and many sided festivity. In the auto de fe, the Church and the State, many times oppossed to one another, showed that their respective powers were united, with all the

- Departament d'História Moderna. Universidad Autónoma de Barcelona. 
intimidatoria de una simbología muy funcional $y$ efectiva, $y$ los componentes mórbidos de identificación personal del mal y la escenificación dramática. intimidating power of a very effective and functional symbolism and the morbid components of a personal identification of evil and the dramatic presentation as a whole.

Es obvio que el origen de las fiestas hay que situarlo en la necesidad humana de liberación de las tensiones que comporta el hecho de vivir. Odo Marquard ha defendido que el sentido básico de la fiesta es el de liberar al individuo de la rutina diaria, lo que él llama la moratoria de la cotidiani$\mathrm{dad}^{1}$. La fiesta es el contrapeso al trabajo y la tensión cotidiana, una descarga periódica de la energía acumulada. Las fiestas religiosas - la mayor parte de las veces, reconversión de las viejas fiestas paganas-, que rompen la actividad laboral cotidiana y se intercalan dentro de lo que se ha llamado el orden pasional del tiempo, son el ejemplo más evidente. Pero, al lado de la fiesta ordinaria y periódica, en el Barroco se irá imponiendo la presencia irregular, discontinua, pero febrilmente intensa, de explosiones festivas que más que la ruptura pactada de la cotidianidad consiguen el efecto de sublimar las pasiones, los temores y las esperanzas de una colectividad. La Contrarreforma, o lo que es lo mismo, el período del absolutismo confesional, de la singular identificación de intereses entre Iglesia y Estado, ayudó mucho a promocionar la fiesta extraordinaria, a normalizar las ocasiones trascendentales que merecian la consiguiente fiesta. Se promovió una campaña de recristianización que intentaba reconvertir los residuos paganos dotando a la mercancía religiosa de alicientes para el consumo popular. Ése es el sentido del tráfico de reliquias e imágenes, del incremento de beatificaciones y canonizaciones -en el siglo xVil hubo 23 de las primeras y 22 de las segundas-, de la introducción de fiestas nuevas con abundantes celebraciones de santos y de la exaltación del aparato ceremonial con procesiones dotadas de gran parafernalia, fundaciones, sermones, rogativas y proclamación de dogmas (Inmaculada...) ${ }^{2}$.

La monarquía explotará, por su parte, la ocasión de hacer espectáculo para un pueblo ávido de emociones. Los acontecimientos familiares de la Casa Real invadirán los espacios públicos y así vemos toda una serie de fiestas ligadas a nacimientos y bautizos, matrimonios, muertes-funerales, exequias-visitas y desfiles regios, juramentos de fueros y otras ordenan-

MARQuard, O., "Una pequeña filosofía de la fiesta", en V. Schultz (dir.), La fiesta. Una historia cultural desde la Antigüedad hasta nuestros dias. Madrid, 1993, págs. 359-366.

Gaficia Carcel, R., Las culturas del Siglo de Oro. Madrid, 1989, págs. 51 y ss. 
zas, victorias y firmas de paz..., utilizados todos estos acontecimientos como pretextos para las concentraciones populares que alimentan el espectáculo. Indudablemente, el hombre del Antiguo Régimen se encuentra sometido a un flagelo sentimental entre el hecho lúdico y el trágico, entre la alegría y la muerte, prácticamente sin frontera entre ambos conceptos. La fiesta es el crisol del conglomerado de sensaciones fuertes que rompían no ya la cotidianidad, como deciamos, sino la mediocridad colectiva. Evidentemente, entre las estrategias de supervivencia que tanto interesan hoy a historiadores como Giovanni Levi, no podemos olvidar la incidencia de la fiesta dirigida por los poderes establecidos para aparcar la memoria de lo negativo - que era mucho-, o para relativizar la desgracia por la vía de la comparación con los infortunios de los poderosos o simplemente para celebrar - por contagio o impregnación- las alegrías de los de arriba. Entre estas fiestas extraordinarias destaca, sin duda, el impacto de los autos de fe, en su doble vertiente de fiesta religiosa y fiesta civil y, al mismo tiempo, elitista y popular.

El auto de fe fue definido así por J. A. Llorente:

"Auto de fe: es la lectura pública y solemne de los sumarios de procesos del Santo Oficio, y de las sentencias que los inquisidores pronuncian estando presentes los reos o efigies que los representen, concurriendo todas las autoridades y corporaciones respetables del pueblo y particularmente el juez real ordinario, a quien se entregan alli mismo las personas y estatuas condenadas a relajación, para que luego pronuncie sentencias de muerte y fuego conforme a las leyes del reino contra los herejes, y en seguida las haga ejecutar, teniendo a este fin preparados el quemadero, la leña, los suplicios de garrote, y verdugos necesarios, a cuyo fin se le anticipan los avisos oportunos por parte de los inquisidores" ${ }^{3}$.

El propio Llorente plantea una variada tipología de autos de fe, de entre la que nos interesa destacar los llamados autos generales. Su principal característica, según el mismo historiador, es la presencia pública de "gran número de reos...". Son éstos, los autos generales, los que nos interesa principalmente analizar en este artículo. Y ello porque nuestro objetivo es, precisamente, subrayar los componentes festivos de los autos de fe, componentes que son especialmente visibles en la magnificencia y carga trascendentalista que tienen estos autos generales de fe.

Sabido es que el auto de fe tenía una dimensión judicial y una vertiente religiosa. En primer lugar, el auto de fe es el escenario de un acto judi- 
cial, el ejercicio público de un tribunal en medio de la tramoya teatral consiguiente. Ese acto judicial es perceptible, según Consuelo Maqueda, a través de las preeminencias de los tablados para reos y tribunal, la presencia de la justicia secular y el púlpito o estrado para la lectura de las sentencias ${ }^{4}$. La jerarquización de los jueces está perfectamente diseñada asi como la de los procesados (gradas más altas para relajados y después las gradas de los demás procesados en función de su sanción penal). La lectura de la sentencia era el eje del acto judicial y su escenografía está, por tanto, muy cuidada. Pero, indudablemente y como su nombre indica, el auto de fe se percibe sobre todo como acto de fe. En este sentido, el auto es el punto donde se encuentran y mezclan intensamente los componentes político-sociales del Antiguo Régimen. Su dimensión religiosa ha sido ampliamente expuesta. Aquí quisieramos resaltar la dimensión de "fiesta espiritual" que tenía el auto para los contemporáneos. No es casualidad que en el siglo XVII Francisco Peña hable del auto como representación del Juicio Final ${ }^{5}$. Toda la disposición escenográfica, la abundante simbología y los estímulos sensoriales y emocionales, acercaban al observador atento a una realidad bien conocida por el común de la población, no por la experiencia sino a través de la naturalista descripción de muchos de los sermones oídos en sus parroquias: ese día apocalíptico en el que todas las almas desnudas ante el Gran Juez, diesen cuenta de sus acciones y pensamientos. Curiosamente, no sólo se ve en el auto de fe una anticipación del Juicio Final. Para algunos de los individuos entre el público era también "una apacible idea de la gloria" ${ }^{6}$. De modo que el auto no sólo podía provocar temor sino también la sensación consoladora de alcanzar con la punta de los dedos un mundo nuevo, por supuesto desigualmente justo, con una fuerte connotación identitaria: ellos, los herejes, desviados, encarnación corporal del demonio; nosotros, los miembros de una comunidad espiritual que ha ejercido la justicia, para desechar de raíz el mal, y la misericordia, para perdonar y acoger a aquellos individuos que muestran arrepentimiento. Ése es el significado de la espada y la rama de olivo en el escudo de la Inquisición. Una auténtica fiesta: jurídica, porque los inquisidores como delegados apostólicos han hecho justicia, y justicia divina, conforme a derecho; religiosa, porque por un momento los creyentes viven la anticipación del Juicio y la Gloria; pero también socio-

Maduf-DA. C.. El auto de fe. Madrid. 1992. pág. 167.

TEDESCH. J., "Organización y procedimientos penales de la Inquisición romana: un bos quejo", en A. Alcalá (ed.), Inquisición española y mentalidad inquisitorial. Barcelona, 1984. págs. 204-205

Gracia Boix, R., Los autos de fe de la Inquisición de Córdoba. Córdoba. 1983, pág. 40 
política, porque el cetro y la cruz, en perfecta simbiosis, actúan al unisono para restaurar al cuerpo social y político dañado. El auto de fe se nos presenta asi como una fiesta multidimensional, poliédrica ${ }^{7}$.

Los autos de fe pueden ser vistos desde tres posibles ópticas. De una parte, la vertiente normativa, jurídica, que establece lo que debe ser el auto de fe. Según F. Bethencourt, el último gran estudioso del tema, desde esta perspectiva no contamos con fuentes que regulen globalmente la normativa ceremonial y ritual del auto, en tanto que el auto fue visto por los tratadistas de la Inquisición siempre sólo como un acto, el último acto del proceso judicial. La esencia del mismo no sería sino la lectura pública y solemne de los procesos y sentencias judiciales a los herejes juzgados. Todo el conjunto del auto quedó olvidado por los juristas descriptores del procedimiento inquisitorial y las cuestiones puntuales de funcionamiento quedaron sólo solucionadas sobre la marcha -aunque crearan la lógica jurisprudencia- por las cartas acordadas. Bethencourt se refiere, con razón, a que la organización de los autos de fe nunca fue planificada normativamente, sino que su montaje fue un ejercicio de "bricolage" pragmático ${ }^{8}$.

La segunda perspectiva es la que enfoca el auto de fe, no desde su presunta regulación previa, sino desde la contemplación directa de su escenificación concreta, lo que realmente fue el auto, que naturalmente prima el contenido ceremonial (la presencia de reos y las efigies de ausentes, la concurrencia de autoridades, la entrega de los condenados al juez ordinario y el dictado y aplicación de las sentencias). Ésta es la vertiente que nos interesa más, en tanto que incide en la proyección festiva del auto de fe y el impacto de éste en la sociedad. Las fuentes proceden de la propia documentación inquisitorial (datos económicos, precisiones respecto a las asistencias, listado de víctimas...) así como de las instituciones colaboradoras en el auto (documentación municipal, real cancillería, información episcopal...).

La tercera vertiente es la que se atiene a la voluntad institucional de lo que se quiso hacer ver que fue lo que se quiere reflejar en la memoria escrita. Los autos dejaron una estela impresa de relaciones que los describian de manera sesgada en tanto que se buscaba asentar en el futuro una determinada imagen o representación de lo que había sido el auto.

MorRenO NAVARRO, I., «Fiesta y teatralidad. De la escenificación de lo simbólico a la simbolización de lo escénico", en José $M^{-}$DiEz BOrouk (dir.). Teatro y fiesta en el Barroco. Madrid. 1986, págs.179-185

Bf thencoufi, F., L'Inquisition à l'époque moderne. París, 1995, pág. 286 
Ésta ha sido, sin duda, la fuente más utilizada, sin el filtro requerido para depurar esa voluntad de manipulación de la memoria.

Ha sido Francisco Bethencourt el que más atención ha concedido al fenómeno de la estrategia de publicación de las relaciones de los autos de fe. En el catálogo de relaciones impresas entre 1721 y 1725 disponible en la librería de Isidro Josep Serrete, se censan un total de 60 que cubren prácticamente todos los tribunales de la Península. En 1724 el Consejo de la Suprema decide centralizar las licencias de publicación, con lo que los tribunales de distrito pierden el control y la difusión de estas noticias. Los relatos del siglo xVill, según Bethencourt, introducen reflexiones sobre el rito, la etiqueta, la significación de los gestos y las palabras. Por otra parte, son expresamente mencionadas la autoridades inspiradoras. Es sorprendente que estas relaciones se multipliquen precisamente en el siglo XVIII, cuando los autos desaparecen de las plazas y se circunscriben al ámbito de las iglesias o a la misma sala del tribunal. Para Bethencourt la razón habría que buscarla en la voluntad de recuperar y reconstruir la memoria de un rito perdido. Las relaciones del siglo XVIII siguen el modelo impuesto por las relaciones de los dos grandes autos de fe del siglo XVII, los autos de Madrid de 1632 y 1680, descritos por Juan Gómez de Mora y José del Olmo, respectivamente. Curiosamente, estas relaciones sólo sirvieron de modelo literario puesto que no hubo más autos de fe con aquella espectacularidad ${ }^{9}$.

¿Cuáles son los ingredientes festivos del auto de fe? Vamos a desgranar, paso a paso, sus diferentes etapas.

\section{LA PREPARACIÓN}

Los preparativos del auto de fe se iniciaban con la publicación del auto con entre ocho y quince días de antelación, aunque el desarrollo de la complicada tramoya escenográfica del acontecimiento, a lo largo de los siglos XVI y XVII, tendió a alargar este plazo hasta el mes. Generalmente,

Relación del Auto de la Fe celebrado en Madrid este año de MDCXXXII, por Juan Gómez de Mora, facsímil, 1986; Joseph del Olmo, Relación histórica del Auto General de Fe que se celebró en Madrid en este año de 1680. Madrid, Roque Rico de Miranda, 1680; F. Bethencourt, op. cit., pág. 289. 
en los tribunales de la Península y a partir de mediados del XVI, se emplazaba el auto en día feriado, domingo u otra festividad religiosa, en contraste con la Inquisición romana. La discusión en torno a si era correcto condenar en día festivo o no, estuvo viva a lo largo del Quinientos, pero finalmente primó la voluntad pedagógica del auto:

«... en dias festivos se podrían pronunciar y ejecutar las sentencias de relajación de reos en causas de fe para que, desembarazado el pueblo de los oficios serviles y mecánicos, pudiese asistir a estos espectáculos y previsiones en los autos generales de fe, y el horror de estas ejecuciones pudiese servir de terror y miedo a los malos para contenerse en la observancia de nuestra religión católica, y a los buenos para segurarse y fortificarse en ella..." ${ }^{10}$.

No obstante, las autoridades seculares podian decretar el día feriado para dar mayor autoridad al evento. Esto parece deducirse de la breve nota del Dietari de la Generalitat de Catalunya referida al auto de fe del lunes 25 de septiembre de 1531: "Aquest dia fonc feriat fins a migjorn per hun acte feren los reverends inquisidors en la plaça del Rey" "1. La fijación de un día feriado especialmente simbólico, como el Corpus Christi, la Ascensión o la exaltación de la cruz, daban al auto de fe un carácter sacramental que se veía reforzado por toda una serie de interdictos: el día del auto se prohibian las misas cantadas y los sermones, así como llevar armas 0 ir a caballo en los alrededores del lugar donde se celebrase el auto; además, se otorgaban indulgencias por cuarenta días a todos los asistentes. Todo contribuia a la percepción de un día excepcional, singular y, por ello, festivo, perfectamente diseñado y controlado por la Inquisición.

En cuanto a su inserción en un ciclo religioso, el ciclo de Pascua y el ciclo navideño, Bethencourt constata que los autos de fe de Lísboa, Évora y Coimbra se realizaron mayoritariamente entre Pentecostés y Adviento. En el caso del tribunal de Barcelona, los autos de fe del siglo XVI se reparten equitativamente sin una preferencia clara en un ciclo u otro. Aunque eso sí, buscando siempre fiestas especialmente señaladas.

La publicación del auto se hacía a dos niveles. En primer lugar, se informaba e invitaba a asistir a las autoridades y personas de calidad del distrito. En segundo lugar, se leía un pregón público por las calles de la ciudad.

Respecto a las invitaciones, sin duda la presencia más anhelada era la del rey por su valor simbólico. Suponia un apoyo ostensible a la actuación

\footnotetext{
MaQueda, C., op. cit., pág. 23.

Dietari de la Generalitat de Catalunya, vol. I. págs. 412-413
} 
del tribunal. Los reyes, sin embargo, dosificaron su presencia a este tipo de actos. F. Bethencourt ha contabilizado un total de 10 autos de fe con presencia real a lo largo de la larga vida del tribunal. $Y$ algunos de estos autos fueron celebrados con motivaciones bastante espurias respecto a la principal razón de ser del auto de fe. Carlos $V$ asistió a su primer auto de fe en Valencia en 1528; los autos de Valladolid de 1559 contaron con la presencia de la regente Doña Juana y el príncipe Don Carlos; el de Toledo de 1560, con Felipe II como espectador, se realizó para celebrar el matrimonio del rey con Isabel de Valois; el auto de 1564 en Barcelona, presenciado por Felipe II, probablemente tuvo una motivación política tras las intensas acusaciones de que fue objeto el tribunal de Barcelona en las Cortes de aquel año; el auto de fe de Lisboa de 1582 fue celebrado en honor de Felipe II, flamante nuevo rey de Portugal; una motivación similar tuvo el auto de Toledo de 1600 al que asistió Felipe III; el auto de fe de Évora en 1619 también tuvo entre sus espectadores a este mismo rey; Felipe IV asistió al auto de 1632 en Madrid en el marco de las fiestas por la recuperación de su esposa, Isabel de Borbón; el auto de 1680 se realizó para celebrar el matrimonio de Carlos II con $\mathrm{M}^{a}$ Luisa de Orleans; y finalmente, Felipe V presidió el auto de fe de Madrid de 1720. Es decir, también para los inquisidores el auto de fe habia trascendido su sentido jurídico-religioso para convertirse en una fiesta singular. En los tribunales periféricos la presencia de los virreyes fue mucho más habitual, impuesta por el rey para neutralizar los conflictos de jurisdicción o de preeminencias, tan habituales en estos territorios.

El pregón público consistía en el anuncio del auto por las calles de la ciudad. No obstante, esta sencilla acción fue adquiriendo complejidad. El auto de Valladolid de 1563 fue publicado por un pregonero acompañado del alguacil y un notario del secreto una semana antes de la realización del auto. Sólo diez años después, en 1573, el auto de fe de Barcelona era publicado por un "corredor" al son de trompetas y atabales que costaron al tribunal 42 sueldos, más un real para el pregonero ${ }^{12}$. El auto de 1632 de Madrid se anunció por las calles con quince dias de antelación al son de timbales y trompetas y con un escuadrón de familiares a caballo. Sin duda la publicación más solemne fue la del auto de Madrid de 1680: el pregón se acompañó de un escuadrón de caballería compuesto por 150 familiares con los símbolos de las órdenes militares a las cuales pertenecían, precedidos por el estandarte de la cofradía de San Pedro Mártir. En los tribunales periféricos, sin embargo, esta ostentación ceremonial de-

AHN, Inquisition. Libro 738, f. 53. 
pendió en buena parte del equilibrio de los poderes y facciones. En Sicilia, a causa de los graves conflictos a raíz de la implantación de la Inquisición, el edicto era publicado sólo por las autoridades seculares sin participación de oficiales ni familiares del tribunal.

La publicación del auto era el disparo de salida para toda una serie de frenéticos preparativos que tenían un considerable impacto no sólo en la sede del tribunal sino también en la ciudad y sus alrededores, generando una ansiedad social que iba in crescendo conforme disminuía el tiempo señalado.

La actividad de orden interno del tribunal se centraba en la puesta a punto de los procesos, en la relación de los reos y en todos los preparativos logísticos, que comprendían una miriada de elementos. La relación de los reos era un documento fundamental para poder iniciar buena parte de los preparativos logísticos. A partir de esa relación se podía establecer con precisión el número de sambenitos e insignias a confeccionar; el número de velas necesarias a adquirir; y la escrupulosa distribución de los reos en la procesión y en el tablado, tanto en función de sus penas como de su estatus social. Una copia de esa relación era entregada al fraile encargado del sermón, generalmente un dominico, aunque también podía ser de otras órdenes religiosas, para que preparase el contenido de su exposición en función de los delitos de los reos. Estas listas de penitentes fueron incluso impresas, entre 1610 y 1620 y posteriormente durante el siglo XVIIl, para repartir el día de la ceremonia, a modo de programa o guión del acontecimiento ${ }^{13}$.

Los inquisidores, en el espacio de tiempo entre la publicación y la vís pera del auto, debían preparar cuidadosamente la escenografía. El lugar de celebración del auto público general era normalmente la plaza de la ciudad, si bien desde finales del siglo XVII se fue realizando cada vez más en el interior de las iglesias mayores. La plaza era, sin duda, el lugar más apto para una fiesta. Con sus balcones, ventanas y miradores, era como una edificación teatral, una especie de "corral de comedias" de grandes dimensiones. En la plaza se construían el cadalso y los tablados. Las gradas - palenques cerraban las calles de entrada a la plaza, formando puente sobre ellas. Al aforo así construido se añadían los balcones de las casas ${ }^{14}$

El cadalso era generalmente de considerables dimensiones: el del auto de Córdoba de 1655 media 38 × 30 m; el de Granada de 1672, 40 × 33 m;

Bethencourt, F., op. cit. pág. 248.

Bonet Cohrea, A., Fiesta, poder y arquitectura. Madrid, 1990, págs. 20-21. 
el de Madrid de 1689, $63 \times 33 \mathrm{~m}$. Sobre el cadalso, elevado del suelo entre 1,7 y $4,8 \mathrm{~m}$, se levantaban dos o tres tablados con gradas, el de los reos, el de los inquisidores y, dependiendo de los tribunales, el de la justicia secular y otras personalidades. Estos tablados ascendían en vertical entre 7 y $9 \mathrm{~m}$., alcanzando la altura de los primeros balcones de la plaza ${ }^{15}$. Esta obra de carpintería exigía en primer lugar un buen trazado, no en vano Juan Gómez de la Mora, trazador y maestro de obras del Felipe III, fue encargado de la traza del cadalso del auto de fe de Madrid de 1632. Pero a partir de esta traza, se imponía el trabajo intensivo en la plaza y sus alrededores de un buen número de carpinteros en los días previos al auto.

No sólo los carpinteros de la ciudad eran movilizados. Una relación de lo gastado en el auto de fe de Barcelona de 1573 da una idea aproximada no sólo del coste económico de estos preparativos sino también de hasta qué punto algunos sectores artesanales se ponían en acción, a las órdenes de los inquisidores, para preparar el auto en todos sus detalles:

A Serra corredor por las trompetas y atabales por la publicacion del auto.. 42 sueldos

A Francisco Soldevila por los tablados... 26 libras

Mas por traher tres enfermos a los tablados, a seis hombres que les lievaron... 18 sueldos

Mas por traher quatro estatuas al tablado... 4 sueldos

Mas a Luys por traher los libros y garbones a la plaça para quemarlos... 2 sueldos

Mas por una carga de garbones para quemar los libros... 5 sueldos y medio

Mas por el verdugo... 5 sueldos

Mas al corredor ho pregonero... 1 real

Mas por limpiar las escalas y patio... 1 real

Mas por la sera que se ha tomado, velas, cirios y hachas... 11 libras, 8 sueldos, 6 dineros

Mas por la colación y almuerzo... 30 libras

Mas por 24 sanbenitos de paño morado con las cruces de paño amarillo... 24 libras

Mas por las manos de los 24 sanbenitos a maestro Rossellón... 16 sueldos

Mas por quatro mascaras por las quatro estatuas... 8 reales

Mas por paya y bastones para batirlas... 6 sueldos

15 Bt IHENCOURT, F., op. cit., pág. 253 
Mas a fray Castellón del Carme por los retulos... 25 reales

Mas por dos manos de papel de forma mayor por los retulos tomados de las de Damian Bages librero... 11 sueldos ${ }^{16}$.

Carpinteros, veleros, sastres, libreros, carboneros, pregoneros... todos ellos se veían involucrados en un acontecimiento que era esperado con expectación en toda la ciudad.

Esta expectación superaba los límites de la propia ciudad. Los inquisidores convocaban a familiares y comisarios para que se integrasen en la procesión del auto. Si el número de estos ministros no era suficiente, se requería la presencia de los familiares de las poblaciones próximas. $Y$, en general, el auto atraía la atención de los lugareños. El 25 de agosto de 1570 se publicaba con una antelación desacostumbrada el auto de fe de Barcelona del 10 de septiembre. Los inquisidores justificaban así esta anomalía: «algunos lugares se quexan diziendo que quando lo saben ya es hecho; como sea de tanto exemplo y necessario que se halle mucha gente se publicó ayer» ${ }^{17}$. Y en 1615 Lope de Vega escribía a propósito de los cortesanos madrileños que acudían a Toledo a ver un auto de fe:

"Aquí han llegado oy notable gente de la Corte, de la mayor y menor gerarquía; he pasado el día razonablemente viendo entrar por la puerta de Visagra tantas diferenzias que, como para todos no debe haber coches ni mulas, es cosa ridicula ver tantas damas en pollinos con sombreros emplumados y rebozinos con oro, no poco preciados de los manteos, que de la misma suerte las conduzen a Toledo los aguadores, que puedieran al Sotillo el día de Santiago el verde. Ay para toda esta maquina cosa de seys ventanas; de suerte que vendrán a verse unos a otros; comerán estremados espárragos y barbos, y bolberanse ${ }^{18}$.

El climax de esta espera llegaba la víspera del auto. Por la mañana se leía un nuevo pregón convocando a la población para la procesión de la Cruz de la tarde y recordando el acontecimiento del día siguiente. Se insistía en la prohibición de llevar armas y circular a caballo en la plaza y sus alrededores y se recordaba la prohibición de misas cantadas y sermones hasta el final del auto y la concesión de indulgencias de 40 días a los asistentes.

AHN, Inquisición, libro 738 , f. 53.

Ibidem, libro 737, f. $249 \mathrm{v}$.

Alonso Burgos, J., El luteranismo en Castilla durante el siglo xvi. Autos de fe de Valladolid de 21 de mayo y de 8 de octubre de 1559. El Escorial, 1983, pág. 104. 
Por la tarde tenía lugar la procesión de la Cruz Verde. Esta procesión tenía una estructura de representación idéntica a otras procesiones medievales. Se asociaba a la petición de misericordia divina para los reos condenados y para los reconciliados recibidos de nuevo en el seno de la Iglesia. La procesión se articulaba en torno a una enorme cruz de madera pintada de color verde, como símbolo de misericordia y esperanza, aunque en algunos tribunales también se incluía una cruz de color blanco, divisa de la cofradia de San Pedro Mártir:

“... y se saca una Cruz de este color, para que colocada en el lugar del suplicio se manifieste la causa porque mueren los culpados... y aunque debiera ser de color rojo y sangriento se pensó que era mejor blanca para que no desmayase la esperanza totaimente" 19.

Esta procesión, que duraba hasta bien entrada la noche, se iniciaba con visperas cantadas en la capilla del tribunal. Al finalizar se abría la puerta de la sede del tribunal para el lento desfile del cortejo. La procesión iniciaba su recorrido por las principales calles de la ciudad, adornadas ya para el acontecimiento. Se encendían las velas y las hachas de todos los asistentes. En algunos tribunales, como el de Granada, Córdoba - el tribunal de Corte, abría la marcha una compañía o batallón de soldados con la misión de proteger el paso de la procesión y mantener el orden. Los soldados, sin embargo, no eran ajenos al significado simbólico de la procesión y con frecuencia se integraban en ella portando «enzinas, zarzas y leñas, símbolos de nuestra redención" o haciendo salvas ${ }^{20}$. Seguía después el estandarte del Santo Oficio. Sobre terciopelo o damasco carmesí resaltaban los símbolos bordados en oro y plata de la Corona y la Inquisición: la cruz en medio; la rama de olivo, simbolo de la misericordia, a su derecha; y la espada de la justicia a su izquierda. El estandarte era portado por alguna persona de calidad o por familiares, seguidos de los comisarios y notarios del tribunal. Aparecían después las órdenes religiosas. El predominio religioso era absoluto en el cortejo, casi una "procesión general de los religiosos de dicha ciudad". Dispuestos según la antigüedad de su orden en cada ciudad, sus hábitos, las velas blancas encendidas, el canto continuo de letanias y del miserere hasta alcanzar el cadalso, en medio de la luz crepuscular, debía provocar en los asistentes una fuerte emotividad y la conciencia de la extremada solemnidad del auto.

Dominguez Ortiz, A., Autos de fe de Sevilla (siglo xvil). Sevilla, 1981.

MAQUEDA, C., op. cit., pág. 222. 
Tras las órdenes religiosas se situaban los representantes de la ciudad, como en el caso del tribunal de Sevilla, en el que asisten ministros del distrito y de la ciudad conjuntamente; nobles, con insignias del Santo Oficio o de sus Órdenes militares, sobre todo en los cortejos más lucidos de los tribunales de Corte y Córdoba; y la capilla de música de la catedral. La cruz verde, símbolo del Santo Oficio, llevada en andas «bajo palio", tapada con velo negro en señal del luto de la Iglesia por los pecadores, era llevada por los calificadores del Santo Oficio que se disponían en doble fila alrededor de la cruz. Les seguían las dignidades eclesiásticas de la Iglesia colegial, familiares y comisarios, el secretario, el receptor, el alguacil mayor con la vara alta del Santo Oficio y, cerrando la comitiva, el fiscal ${ }^{21}$. Los cortejos más elaborados eran los de los tribunales de Corte y de Córdoba, pero las variaciones eran considerables. En algunos tribunales no aparecen los representantes de otras instituciones; los familiares no tenían un puesto fijo en la comitiva; el receptor no siempre estaba presente... En realidad, los cortejos de las procesiones, tanto la de la cruz verde como la del día del auto, se fueron elaborando progresivamente a "golpe" de carta acordada. La ausencia de una normativa clara, por un lado, y la necesidad de encontrar puntos de encuentro entre los poderes fácticos locales, siempre especialmente susceptibles en cuanto a sus preeminencias y jurisdicción, determinó en buena medida estas variaciones. Un caso extremo sería el del tribunal de Barcelona. Frente a la descripción anterior, la procesión de la cruz en esta ciudad tiene un aspecto desvaido:

«En aquest dia, aprés dinar, entre quatre y sinc hores, tot lo clero de la comunitat de la sglésia de Santa Maria de la Mar de la present ciutat de Barcelona,... ab la creu alta y las banderas de la Vera Creu, muntà a la casa dels reverents pares inquisidors... y de alli prengueren una creu de fusta ampla, pintada de vert, la qual portave lo vicari de dita sglésia... anant al mig del diacha y sots-diacha ab capa professional negre, cantant tot lo clero lo Miserere rasat, y aixi aportaren, lo dit clero ab dita creu y banderas de la Vera Creu, de la dita casa dels reverents pares inquisidors ab profassó, que molta gent anava ab ella» 22 .

Bethencourt describe la procesión correspondiente al auto de 1627 en Barcelona, constatando la presencia de familiares y notarios, además del clero de Santa María del Mar. Pero en ninguna de estas breves descripi-

21 Hemos descrito una comitiva tipo, aun a sabiendas de que las peculiaridades y diferencias entre los tribunales en cuestiones de asistencia y preeminencias, fueron múltiples, tanto en esta procesión como en la del día del auto.

22 Dietari, vol. II, pág. 376. 
ciones se hace referencia al estandarte de la Inquisición o al papel de las órdenes mendicantes.

El recorrido de la procesión finalizaba en el cadalso. Alli se entronizaba la cruz verde, velada, permaneciendo en el altar hasta el día siguiente, iluminada por hachas blancas y custodiada por familiares, religiosos y/o soldados. Durante toda la noche los religiosos celebraban misas y cantaban maitines y laudes. En los tribunales en los que se incluía la cruz blanca en la procesión, una vez entronizada la cruz verde, la comitiva se dirigía al quemadero. Allí se colocaba la cruz en un altar, custodiado por familiares y soldados.

El significado de esta procesión era muy evidente: el verde, color litúrgico de tiempos ordinarios, daba idea de esperanza. El velo negro que cubría la cruz simbolizaba el luto de la Iglesia por los pecadores aún no reconciliados.

A lo largo del siglo XVII esta procesión fue enriqueciéndose. En los tribunales castellanos la participación de los nobles, muchos de ellos familiares, o nombrados expresamente para el auto, llevando el estandarte, se hizo habitual. Otra nota distintiva fueron los frecuentes enfrentamientos entre franciscanos y dominicos ${ }^{23}$.

\section{LA PUESTA EN ESCENA: EL AUTO}

Sobre las dos o tres de la madrugada se ponía en marcha el complicado engranaje del auto de fe. A esa hora, un inquisidor, el secretario y el alcaide debían entrar en las cárceles e imponer a los presos sus insignias «según su culpa, a los reconciliados sambenitos y velas, a los relajados sus sambenitos y corozas, poniendo cada uno en su lugar para que no se pervierta el orden, a la postre se dejan los relajados...» ${ }^{24}$. Sólo los condenados a relajación habían sido avisados anteriormente de la sentencia de sus procesos, con el fin de que se preparasen para morir. Asimismo, todos ellos habían realizado una ligera colación la noche anterior consistente en fruta de sartén, ensaladas, cidra confitada, camuesas, cardos, frutos secos, ciruelas, pan y vino ${ }^{25}$.

23 De ambas caracteristicas puede verse un buen ejemplo en la Relación del Auto de la Fe celebrado en Madrid este año de MDCXXXII, por Juan Gómez de Mora, facsímil, 1986.

24 Jimenez MONTESEFin, M., Introducción a la Inquisición española. Madrid, 1980. Instrucciones de Espinosa, 1570.

25 Este "menú" costó al tribunal de Barcelona, en 1572, 148 sueldos: AHN, Inquisición, libro 737, f. 345 . 
Entre las cinco y las siete de la mañana se iniciaba la gran procesión, que constaba de dos segmentos: el cortejo de los reos y el cortejo del tribunal. La salida del cortejo de los reos debía provocar gran impaciencia porque el secreto impuesto por la Inquisición a sus funcionarios y prisioneros liberados incitaba, seguramente, a la expectación curiosa. El pueblo podía conocer el tipo de pena infligido a los prisioneros gracias a su posición en el cortejo y a su vestimenta. El cortejo lo abrían los familiares que se distribuían en filas alrededor de penitenciados y reconciliados. El orden de los reos era gradual, de menor a mayor pena: absueltos ad cautelam, penitenciados, reconciliados de levi, de vehementi, y relajados. Estos últimos eran flanqueados por dos religiosos con el objetivo de confortarles en sus últimos momentos y, si era posible, llevarlos al arrepentimiento antes del suplicio para que muriesen en el seno de la Iglesia. Detrás de los relajados seguían las estatuas de los reos huidos o muertos "con dos inscripciones en pecho y espalda con nombre, patria, delito y la denominación de muerto o fugitivo". Estas estatuas llevaban su correspondiente sambenito y unas máscaras, simulando el rostro del condenado. A las estatuas seguían los cajones de huesos, en los que se transportaban los huesos de los reos muertos para quemarlos junto a su estatua. La desmemoria debía ser completa.

Entre las insignas de los reos, el sambenito tenía un fuerte significado simbólico. Era, en general, de color amarillo, simbolizando la traición; el rojo de la cruz de San Andrés, en el caso de los reconciliados, o de las llamas y diablos, de los relajados, simbolizaba la cruz asumida por Cristo y los mártires. Había también diferencias en el sambenito de los reconciliados en función de su pena: los de levi sólo llevaban un aspa de la cruz de San Andrés. Todos ellos se cubrian con capirote o mitra que representaba la degradación religiosa, la falsedad del heresiarca y el escarnio al que debía ser sometido por su delito. Todos los reos llevaban cirios en sus manos, blancos o verdes, pero en cualquier caso, apagados. Sólo tras la ceremonia de abjuración y reconciliación esos cirios se encendían. El cirio en la liturgia era el símbolo de la luz divina que ilumina las tinieblas, de ahí su uso reservado a los reconciliados. También en este aspecto el tribunal de Barcelona ofrecía algunas peculiaridades. Los sambenitos no eran de color amarillo sino de paño morado, un color también con fuerte carga litúrgica, que simbolizaba el sacrificio de Cristo y la expiación de pecados. Estos sambenitos morados llevaban cosidas las cruces de San Andrés en paño de color amarillo ${ }^{26}$. Otras insignias de los reos eran las sogas al

\footnotetext{
26 Dieciséis sueldos tuvo que pagar el tribunal a un artesano para su confección: AHN, Inquisición. libro 738, f. 53; las Instrucciones de Espinosa contemplaban esta variable, JIMÉNEZ Munteserin, M., op. cit., pág. 219.
} 
cuello y los bozales en las bocas, una especia de mordaza para evitar imprecaciones y herejías.

A los familiares, reos y religiosos, seguia el alguacil mayor del Santo Oficio con vara alta, los comisarios, los calificadores y, finalmente, un inquisidor. Un último detalle: la salida de la procesión de los penitentes era señalada por la campana de la catedral, seguida por la de todas las iglesias de la ciudad.

El cortejo de los reos era el primero en llegar al cadalso. Su aparición en la plaza tenía una componente dramática especialmente intensa: las oraciones de los religiosos del cortejo se unian a las últimas palabras de los maitines y misas celebrados en torno a la cruz verde por los padres dominicos. Las hachas encendidas adquirían una nueva tonalidad con las primeras luces del día. Y todo el ambiente de la plaza respiraba el incienso ofrecido durante la noche. En algunos tribunales, las voces se unían para entonar el cántico Veni Creator Spiritus. Los reos, mientras, subían al cadalso y se colocaban en su tablado correspondiente según un protocolo muy preciso: de arriba a abajo en función de la gravedad de sus condenas. En la grada superior los relajados. Debajo, los reconciliados según su orden. Finalmente, los absueltos ad cautelam. Con ellos se sentaban los religiosos y familiares encargados de su custodia.

Poco después del cortejo de los reos salía de la sede del tribunal el cortejo de los inquisidores. Tampoco para este cortejo hay un orden único. Las dos constantes de todos los cortejos son, en primer lugar, el estandarte del Santo Oficio, que ocupa un lugal central en la procesión y es portado por el fiscal; en segundo lugar, la comitiva la cierra en un lugar preeminente el inquisidor más antiguo, generalmente flanqueado a su derecha por el obispo y a su izquierda, por un representante de la justicia secular: un corregidor (tribunal de Murcia) o el presidente de una sala de la Chancillería (tribunales de Granada o Valladolid). Aparte de estas constantes, las variaciones se producian en función del estatus social y, especialmente, de la realidad jurisdiccional vivida por cada tribunal de distrito. El cortejo del tribunal de Corte estaba condicionado, sin duda, por la asistencia de los miembros del Consejo de la Suprema y la necesaria integración de los ministros del tribunal de Toledo y los propios en aquellos autos que realizaban conjuntamente. En el tribunal de Granada, los enfrentamientos jurisdiccionales con la Chancillería determinaron que el cortejo finalizase con el presidente de la Real Chancilleria, seguido de su caballerizo y un alguacil de corte, y el inquisidor más antiguo, con su capelete y en la cabeza insignias de legado de su Santidad. En el tribunal de Barcelona, los conflictos jurisdiccionales dieron lugar a una alternativa 
cuando menos singular: cuatro comitivas simultáneas y diferentes, la del tribunal, en la que se integraban los nobles y caballeros, miembros del capítulo de la catedral y los ministros del Santo Oficio; la del obispo de Barcelona, que integraba a todos los prelados del Principado y al arzobispo de Tarragona; la del Virrey, acompañado de los miembros de la Real Audiencia; y, finalmente, la de los consellers de Barcelona y diputados de la Generalitat. Parece que en algunas ocasiones el obispo se integraba en el cortejo de los inquisidores pero, para sorpresa de éstos, no en el lugar preeminente que tenía en otros tribunales:

“... yendo el arzobispo [de Tarragona] y obispos delante del estandarte
junto a los señores de título que acompañan a los inquisidores y aunque pa-
rece algo reçio que los obispos no vayan junto a los inquisidores en el
acompañamiento la costumbre desta tierra ha sido esta y con los que tanto
guardan las suyas es de importancia no perder el officio las que hasta aquí
ha tenido porque con pocas que pierda quedara sin ninguna segun le han
desautorizado ${ }^{27}$.

En general, las cartas acordadas y cédulas reales, a partir de la segunda mitad del siglo XVI, obligaron a las autoridades seculares a asistir al cortejo en señal de apoyo a la actuación del Santo Oficio. Los conflictos fueron tratados individualmente. Según Bethencourt, la procesión del tribunal evolucionó en tres direcciones. En primer lugar, los lugares de todos los oficiales y ministros del tribunal fueron progresivamente revalorizados respecto a sus colegas de otros tribunales de justicia y consejo de la Corona con funciones semejantes. Por otro lado, la representación de la nobleza aumentó cuantitativa y cualitativamente a lo largo del XVII, como revela la presencia de grandes y titulados. Finalmente, la presencia del poder civil se diversificó, especialmente en los autos de fe de Madrid o los grandes centros del Imperio ${ }^{28}$.

Lo cierto es que una compañía de soldados o alabarderos; un número considerable de familiares y nobles a caballo; los ministros y oficiales del tribunal; el fiscal con el estandarte de la fe en alto; la justicia secular; las autoridades locales; el capítulo de la catedral; $y$, por fin, los inquisidores, arropados por el obispo y el presidente de la Audiencia, ofrecían una visión festiva extraordinariamente rica en matices. Los nobles y caballeros vestidos con sus mejores galas y portando las insignias del Santo Tribunal o de sus Órdenes Militares, las armas relucientes, los caballos engualdrapados con sedas de colores... todo ello contribuye a esa percepción. 
Asimismo, la presencia de todas las instituciones, de todos los poderes, tiene un mensaje subliminal no despreciable: todos se unen bajo el mando inquisitorial para estirpar el cáncer social y religioso de los transgresores. El espectador, desde su estatus social, forma parte también de esta comitiva; aunque en principio tiene una participación pasiva, son necesarios sus ojos, son necesarias sus miradas curiosas y asombradas, para realzar lo sublime de ese cortejo. El cortejo es espectáculo, mas espectáculo pedagógico. Pero este espectador no tiene una visión estática. Ante sus ojos ha pasado otro cortejo antes, el de los reos. Y el mensaje, en dimensión diacrónica, sigue teniendo una claridad meridiana: existe una separación abismal entre los infames y los puros, entre los condenados y los que se saben cerca de la gloria, entre los penitenciados que esperan misericordia y aquellos que tienen conciencia de que la administración sacramental de la piedad y la justicia les pertenece.

Al llegar a la plaza, los inquisidores ocupaban su lugar en el correspondiente tablado, también siguiendo un orden específico. En la grada más alta el inquisidor más antiguo, con silla y dosel, en algunos tribunales rodeado por el obispo y el corregidor. El resto de inquisidores, los notarios del secreto, el receptor, los secretarios y demás personal, se distribuían en las gradas siguiendo un estricto orden de prelación. Los representantes de las otras jurisdicciones eclesiásticas y seculares disponían, en algunos tribunales, de un tablado específico, o bien ocupaban las ventanas y balcones de la plaza.

Con la asistencia real, el mensaje del auto se magnificaba hasta convertirse en un reflejo del esplendor del poder. Ejemplos paradigmáticos de este esplendor barroco son las relaciones de los autos de fe de Madrid de 1632 y 1680 . Los autos generales con asistencia real se complicaban extraordinariamente, buscando la concreción máxima de asientos y preeminencias. El lugar del rey y su cortejo en las mejores ventanas y miradores de la plaza determinaba la situación del resto de autoridades y de la nobleza. En los tribunales periféricos, el virrey también ocupaba un lugar privilegiado. En Cataluña, virrey, obispo, consellers de Barcelona, diputados y miembros de la Real Audiencia, participaban normalmente del auto desde las ventanas de los edificios adyacentes a la plaza del Born. Sólo los miembros de la Real Audiencia que votaban con los inquisidores los delitos de jurisdicción mixta, como era el de sodomía, podían ocupar un lugar en el tablado de los inquisidores.

Visualicemos por un momento el complicado escenario humano que hemos visto construirse hasta aquí. En medio de la plaza se levantaba el cadalso, de generosas proporciones, con forma rectangular o cuadrangu- 
lar. A los lados del rectángulo, dos tablados opuestos, con gradas, daban cabida a reos e inquisidores. Ambos grupos, frente a frente, marcaban un imaginario espacio simétrico, pero abismalmente desigual. La decoración, los colores, los gestos, marcaban esa diferencia. La sobriedad del tablado de los reos frente al dosel, los pendones, las alfombras, las sedas y terciopelos, bordados en oro y plata, del tablado de los inquisidores. El amarillo, el rojo, el morado de los paños, y el verde y blanco de los cirios eran los colores de los reos, frente a la riqueza de matices cromáticos de los inquisidores y sus ministros. La mezcla de miedo, angustia, esperanza, ira... en los rostros del tablado del mal, frente a la circunspección, la satisfacción del deber cumplido y la íntima complacencia por la presencia subordinada del resto de jurisdicciones, del tablado del bien. $Y$ entre estos dos tablados, un espacio central en el que se situaba el altar de la cruz verde, rodeado de hachas encendidas, un segundo altar para celebrar la misa y un pequeño púlpito desde el que se predicaba el sermón y se leían las sentencias. Al fondo, una mesa para los secretarios del tribunal y sobre ella la arquilla donde se guardaban las sentencias. Finalmente, nobles y autoridades desde ventanas y balcones y el pueblo desde la plaza y las calles adyacentes, completaban el espacio escenográfico, un espacio sacralizado, muy próximo al auto sacramental que se representaba en las iglesias.

Esta instantánea no nos permite apreciar los variados intereses de todos los que asistían al auto. Las expectativas podían ser tan divergentes como las que nos describe el anónimo autor de la Relación del auto de Valladolid de 1559:

"Los caminos que venian a la Villa tan llenos i acompañados de jentes, como las mismas calles, i finalmente era tanta la jente que se halló este dia a ver el tal espectaculo, que parezia una jeneral congregacion del mundo i tanto, que, perdía la esperanza de poder, no oir lo que habia de pasar. Unos se contentaban con ver, otros con el aparato de cadalsos, otros con ver la diversidad de jentes, naziones i lenguas presentes se hallaban e inpedian el paso de las calles, i otros con ver la grandeza del pueblo i majestad con tantos Señores i Caballeros del Reino, otros con ver la belleza y hermosura, ricos atavios de tantos Señores i Señoras, de Damas cortesanas prinzipales, naturales i forasteras, que ocupaban las ventanas de las calles i plazas por donde venian los penitentes, por manera que la plaza, calles, tejados i ventanas del pueblo estaban tan llenas de jentes de diversas Naziones i tan congregados, que parezia propio retrato del juizio" ${ }^{29}$.

Alonso Burgos, J.. El luteranismo..., pág. 110. 
La sacralización del auto de fe tiene su pleno sentido en la inserción del auto en el curso de la misa. El auto se iniciaba con el sermón, general- mente una pieza de oratoria de entre quince minutos y una hora, dedicado a ahondar en los tipos de delitos condenados en el auto, con una función pedagógica y disuasoria evidente, y a exaltar la actuación del Santo Oficio. Al sermón seguía el juramento, al que debían someterse todos los presentes. Si el Rey asistía, era el Inquisidor General el encargado de tomarlo. En el resto de ocasiones, la función recaía sobre el secretario del tribunal. Los asistentes se ponían en pie "y con la mano levantada, formaba con los dedos la señal de la cruz» y respondian al juramento leído por el secretario. Todos los asistentes se implicaban oral y gestualmente en la lucha contra la herejía y en el apoyo y favor al Santo Oficio en esa batalla. Todos, pero no en todas partes. Los inquisidores del tribunal de Barcelona, por ejemplo, no consiguieron el juramento de las autoridades presentes en el auto de fe de 1573. A una consulta previa, la Suprema respondía que debian consultar con el virrey la posibilidad de lograr el juramento "y si no, que no se pongan en cosa con que no hayan de salir». Aún estaban muy recientes los fuertes conflictos entre la Inquisición y las autoridades del Principado en $1569^{30}$.

Al juramento seguia la publicación de las sentencias. Esta publicación se inserta justo antes del ofertorio, en el lugar donde en las misas parroquiales dominicales la ejecución de penitencias públicas era impuesta por las justicias eclesiásticas ${ }^{31}$. La lectura la hacía el secretario o bien el notario del secreto. Los reos eran llamados uno a uno, descendiendo de su tablado hasta el espacio central del cadalso a través de un corredor de madera llamado popularmente "calleja de la amagura». En algunos autos, los reos debían "oír sus sentencias en una como jaula volada hacia el frente del altar» 32 .

Una vez acabada la lectura de los resúmenes y sentencias se procedía a la relajación. Se entregaban los condenados a la justicia real pidiendo encarecidamente que se usase misericordia con ellos. Los representantes de la justicia secular recibían a los reos y asumían como propia la sentencia implícita en la condena de relajación. Los reos eran condenados a muerte, bien fuese a la hoguera directamente, o al previo garrote u horca. Leidas estas sentencias, los funcionarios reales, acompañados de los re-

\footnotetext{
AHN, Inquisición, libro 737, f. $433 \mathrm{v}$; ; una buena interpretación de este conflicto en $R$. Garcia CARCEl, Felipe $1 /$ y Cataluña. Valladolid, 1997, págs. 78 y ss.

DEDIEU, J.-P., L'administration de la foi. Madrid, 1989, pág. 272.

MAQUEDA, C., op. cit., pág. 379.
} 
ligiosos encargados de asistir a los reos y algunos funcionarios del tribunal, en concreto un secretario para levantar acta de la muerte, conducían a los condenados al Quemadero, generalmente en las afueras de la ciudad, donde se procedía al cumplimiento de las sentencias. El concurso de gentes en esta fase que, en un sentido estricto, ya no forma parte del auto de fe, dependía en buena parte de la popularidad de los reos y de la singularidad de los delitos.

Entre tanto, en la plaza, los inquisidores hacian una pausa para el almuerzo, al que solian invitar a todas las autoridades civiles y religiosas. Un tribunal con continuos problemas económicos como el de Barcelona, hacía el siguiente dispendio en $1572^{33}$ :

\author{
"Pescado para empanadas... 88 sueldos \\ Peces para freír... 20 sueldos \\ Aceite... 10 sueldos \\ Especias... 5 sueldos \\ Camuesas, ensaladas y hubas... 4 sueldos \\ pan... 40 sueldos \\ dos barrelones de vino... 25 sueldos \\ 1 Arroba de harina para empanadas... 12 sueldos \\ Fruta de sartén... 16 sueldos \\ nueces e higos... 4 sueldos \\ De hazer aderezar la comida... 16 sueldos \\ Cazuelas para aderezar todo... 4 sueldos".
}

Un total de 244 sueldos. Dos años más, tarde, en 1575, en el informe del auto se hacía constar que no se había dado colación ni almuerzo para ahorrar este gasto ${ }^{34}$. En cualquier caso, los excesos en estos almuerzos llevaron a la Suprema a limitar las invitaciones a oficiales, penitentes y confesores y a tasar el gasto ${ }^{35}$.

Acabado el almuerzo, el auto de fe se reemprendía con la abjuración de los penitenciados y reconciliados. Éstos bajaban del tablado en pequeños grupos con sus velas en la mano y se arrodillaban ante el altar. El secretario del Santo Oficio leía las fórmulas de abjuración, formali, de vehementio de levi, que ellos debían repetir y firmar en el libro donde se hacía constar. Seguidamente, el inquisidor recitaba un exorcismo que concluía con el Miserere Mei, Deus, cantado por la capilla real. A este salmo seguian nuevas oraciones del ritual romano. Finalmente, mientras

AHN, Inquisición, libro 737, f. 345

Ibidem, libro 738, f. 170.

MAOUEDA, C., op. cit., págs. $440-401$ 
el coro entonaba el himno Veni Creator Spiritus, todos los asistentes se ponían de rodillas durante las cuatro primeras estrofas. Una vez acabado el himno se desvelaba la cruz verde y se encendian las velas de los reos. El inquisidor daba la absolución ad cautelam a los penitentes, los reintegraba "al gremio y unión de la santa madre Iglesia Católica y le restituimos a la participación de los Santos Sacramentos y comunión de los fieles y Católicos Cristianos della»; se añadían las penas de cárcel, el tiempo durante el que debían llevar hábito y "que todos los Domingos y Fiestas de guardar le hubiera en la Iglesia Catedral della, con los otros penitentes" ${ }^{36}$.

El auto de fe continuaba hasta el final de la misa. Sólo entonces se daba por concluido el auto.

El análisis del auto de fe en su vertiente de fiesta nos permite superar la vieja polémica de la historiografía liberal y la historiografía conservadora en torno a la popularidad de la Inquisición. La historiografía conservadora del siglo XIX buscó uno de sus argumentos en defensa de la Inquisición en la presunta popularidad del Santo Oficio, cuyo testimonio más evidente sería la asistencia masiva de gente a los autos de fe. El jesuita Ricardo Cappa, en su defensa apasionada de la Inquisición, afirmaba:

"Los millares de personas que libre y espontáneamente asistían a los autos de fe, la paciencia invencible con que por ocho o nueve horas oian la lectura de los sumarios, las abjuraciones y reconciliaciones públicas, el religioso silencio que reinaba en estos actos, todo indica que el pueblo se identificaba con ellos. La enemiga del pueblo contra todo reo de Inquisición era tan grande, que a veces se hacia indispensable esconderlos, o entrar de noche en los lugares, para librarlos del furor de la gente» ${ }^{37}$.

La historiografía liberal ha negado siempre esta popularidad atribuyendo la asistencia a sentimientos morbosos que nada tenian que ver con una identificación con el Santo Oficio. Recuérdese, al respecto, lo que dice de los autos de fe Antoni Puigblanc:

«El auto general de fe, visto el aparato con que se ha executado, puede en cierto sentido llamarse función augusta, y muy adequada para producir en el vulgo la más respetuosa admiración hacia este tribunal. Basta decir que ha

Ibidem, pág. 391

CAPPA, R., La Inquisición española. Madrid, 1888, fac. 1994, págs. 169-170. 
sido un remedo del triunfo romano, y como una representación anticipada del juicio final, para conocer que ha reunido las dos más grandiosas ideas, que ocuparon jamás la imaginación. Cuando para convencernos de semejante observación no tuviéramos el testimonio de la Inquisición misma, que en todos tiempos ha hecho alarde de ello, las ceremonias que al efecto ha adoptado no permitirían dudásemos un momento de esta verdad (...). Los tratadistas de este tribunal le llaman horrendo espectáculo, y capaz de aterrar a cualquiera; ¿que mucho pues que los inquisidores hayan infatuado con él al pueblo, haciéndose más temibles que la misma autoridad civil, a pesar de ser ésta la que por una fatal liberalidad les comunicó tamaño poder?" 38 .

Quizá las consideraciones que hemos hecho del auto de fe como fiesta en la que se conjuga el ejercicio de un tribunal judicial con la exhibición de poder compartido por la Iglesia y el Estado, con toda la capacidad intimidatoria de una simbología muy funcional y efectiva, y los componentes mórbidos de identificación personal del mal y la escenificación dramática del sufrimiento humano, puedan superar la dicotomía popularidad/repulsión social a la que nos hemos referido. El auto de fe fue, sin duda, una fiesta compleja. Religiosa, puesto que su eje temático era un juicio religioso, ensayo del juicio que tras la muerte pende sobre las conciencias de todos los hombres. Su sustrato era el problema de la herejía, la identificación del mal y su necesaria penalización para rearmar los valores de su contrario: el bien. El auto de fe era una fiesta religiosa porque enseñaba, con pedagogía efectiva y efectista, el sentido finalista de los actos buenos y malos y demostraba pública y ostentosamente que la Iglesia tenía el monopolio absoluto de la coacción en este ámbito. Pero al mismo tiempo era una fiesta política, porque los poderes civiles, estatales y locales, tenían su protagonismo, si no en la identificación del mal, si en la aplicación penal y porque el absolutismo confesional dotó al juicio eclesiástico de todo el aparato administrativo que necesitaba para su oficialización y multiplicación de su resonancia pública. Iglesia y Estado, tantas veces enfrentadas, mostraban a través del auto de fe sus respectivos poderes concertados. La Iglesia ponía los ritos. El Estado, sus mitos. Todo ello bien escenificado, con abundante público consumidor.

No tiene sentido debatir sobre la popularidad del Santo Oficio en función de ese público, porque ese público fue sólo el consumidor, nunca el productor de la fiesta. La popularidad no procedía de la institución sino de la fiesta oficial -religiosa y laica, al mismo tiempo- que el ejercicio de

\footnotetext{
PuigBI ANCH. A., La Inquisición sin máscara. Barcelona, 1988, págs. 193-196.
} 
la práctica inquisitorial implicaba. La asistencia abundante a los autos de fe, a la fiesta pública inherente a los mismos, no presupone forzosamente identificación con la institución organizadora de tales actos. El espectáculo festivo, con el impacto visual, el despliegue organizativo, la exhibición pública del poder, la presentación de las victimas... fue, sin duda, popular, como popular sería cualquier fiesta oficial con todos sus ingredientes. La participación pasiva en la fiesta jamás tiene por qué suponer una identificación ideológica con las instituciones que la promueven, como ha sostenido la historiografía conservadora, ni desde luego cabe apelar a un supuesto sentido necrófilo, el culto a la muerte, el amor a la violencia de los españoles, propia de unas presuntas esencias caracteriológicas españolas, que tanto destacó Unamuno.

Ni esencialismo español ni identificación ideológica. La popularidad del auto de fe es la popularidad de la fiesta, de cualquier fiesta con similares artificios.

Otro tema es el del presunto diferencialismo catalán con respecto a los autos de fe, la supuesta sobriedad de los autos de fe en Cataluña. Los inquisidores de Barcelona tenian conciencia de su singularidad (1622):

\begin{abstract}
"es singular en España en razón de no hacerse los autos de fe con la grandeza y decencia que se hacen en todas las demás inquisiciones y que esta inquisición es muy pobre y asi lo que se habia de hacer en autos públicos será más conveniente que se haga en alguna iglesia cuando esto sea necesario" ${ }^{39}$.
\end{abstract}

La explicación de esta devaluación de los autos en Cataluña es ante todo económica, en función de la capacidad económica de Cataluña, sumida en los siglos XVI y XVII en una penosa situación de crisis, y política, debido a la ausencia de la corte y la penosa periferización de la monarquía en Cataluña.

Las quejas continuas por la difícil situación económica son abundantes en la correspondencia del tribunal. Ya hemos visto cómo a partir de 1575 se suprimió la colación y almuerzo del auto. En 1607, se hizo auto en la sala grande junto al palacio para evitar los gastos del cadalso; y lo mismo ocurrió en $1609^{40}$. También a principios de 1575 se ordenó el despacho de las causas de los presos pobres sin esperar al auto, puesto que su sustento corría a cargo del tribunal. El déficit de aquellos años era consi-

39 Cit. en BADA, J., «El Tribunal de la Inquisición en Barcelona, ¿un Tribunal peculiar?, Revista de la Inquisición, 2 (1992), pág. 119.

40 AHN, Inquisición, libro 741 , f. 282 r. y 329 r. 
derable. El receptor se quejaba en 1569 de haber gastado 12.000 reales en la alimentación de los presos y sólo haber recuperado 2.000 a través de las confiscaciones ${ }^{41}$. Su informe del auto de 1577 no podía ser más desalentador: no podría ingresar nada en el arca "visto la pobresa dél (tribunal) y lo poco que nos podemos engrassar de la hazienda de los reconciliados". En cualquier caso, el auto "aunque pobre empero ha sido muy honrroso y de grandissimo exemplo» ${ }^{42}$.

Por otro lado, los roces prácticamente constantes entre la Inquisición y el resto de justicias y autoridades, tantos eclesiásticas como seculares, determinaron en buena medida un funcionamiento peculiar en el tribunal de Barcelona. Recordemos las cuatro comitivas simultáneas el día del auto, los asientos de miembros de la Real Audiencia junto a los inquisidores y la ausencia de juramento. Comprensiblemente, acostumbrados a la grandeza de autos de fe como los de Córdoba, Sevilla, Toledo o Valladolid, los inquisidores del tribunal de Barcelona debian tener una opinión devaluada de los autos de fe catalanes y una actitud a la defensiva. Sus informes hacen hincapié necesariamente en aquellos aspectos que justifican su actuación en todo lo concerniente al auto de fe. Asi en 1552, el escaso número de reos se justifica por la ausencia de heterodoxia en Cataluña, pero ello no ha sido óbice para que el auto fuese un éxito pues. to que su infrecuencia hace que "éste se ha tenido en tanto y en más" ${ }^{43}$. En 1577 dos informes distintos valoraban la popularidad ( "huvo gente desde el principio hasta el cabo del aucto, que no se podía pasar por ninguna parte") ${ }^{44}$; y la presencia de autoridades: "fueron los inquisidores acompañados del conde de Aytona, del justicia de Aragón, de muchos cavalleros y de otra gente... Ha sido todo a lo que puedo juzgar muy bien guiado y con toda auctoridad" 45 .

En ningún caso, creo que pueda atribuirse esta devaluación de los autos de fe en Cataluña a peculiaridades caracteriológicas catalanas, a una presunta incapacidad festiva de los catalanes, como tantas veces tópicamente se ha escrito, sublimando por contraste, el valor trabajo y el valor ahorro (aquella imagen de Tornamira de Soto que sostenía que «por la esterilidad de la tierra o por su natural templanza, son tan solícitos de lo porvenir, que apenas gozan de lo presente $")^{46}$. La verdad es que un mi-

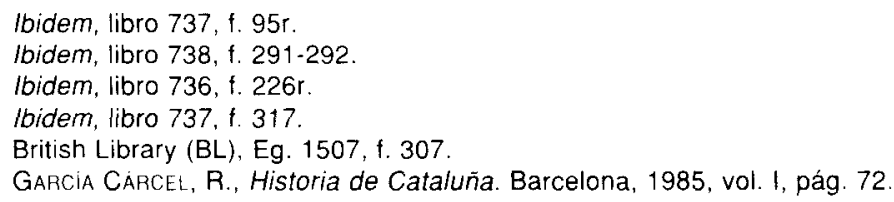


nucioso examen de los Dietarios municipales o de la Generalitat catalana nos da una imagen muy distinta, de un pueblo, el catalán, dedicado plenamente a la fiesta. La tesis de licenciatura de Isabel Lobato es un buen testimonio de esta singular capacidad festiva de los barceloneses ${ }^{47}$.

Las fiestas religiosas que movilizaron más la participación activa de los barceloneses en los siglos XVI y XVII fueron, sin duda, la procesión del Corpus - que implicaba la representación de entremeses con temas religiosos- y la procesión de la Asunción de la Virgen y la de la Inmaculada. En esta última participaban sobre todo los estudiantes universitarios desde que la Universidad de Barcelona asumió el juramento de la creencia en la Inmaculada a partir de 1618 (el dogma sería proclamado en 1854). También generan masivas adscripciones populares fiestas como la de Santa Eulalia - utilizada como reclamo para demandar Iluvia - o San Roque - su procesión buscaba la intercesión frente a la peste--; la canonización de San Raimundo de Peñafort en 1601 fue, asimismo, foco generador de grandes manifestaciones populares.

Pero, sobre todo, proyectaron la gente a la calle las fiestas de rogativas por enfermedades, hambres o situaciones de extrema necesidad que impulsan a buscar el poder taumatúrgico de la religión (la peste de 1564 puso en la procesión a unas 12 ó 14.000 personas, la sequía de 1566, la peste de $1589 . .$.$) . También generan notables despliegues populares los$ Tedeums de gracias por éxitos militares o políticos (Lepanto, la victoria de Felipe II sobre D. Antonio, prior de Crato...).

El sentido intrísecamente lúdico de la fiesta se constata en las abundantes fiestas laicas que se celebran en las calles de Barcelona. Las entradas de personajes ilustres (sobre todo si son reyes o miembros de la familia real) movilizan mucha gente "ab sons, balls, mascaras i altres invencions de jocunditat i alegrias honestas", que contemplará asimismo, cabalgadas de todo tipo y exhibición de élites ciudadanas (luminarias, música...).

La fiesta popular tuvo enorme éxito en Cataluña. Y ahí están como testimonio la proyección del Carnaval, la clásica fiesta de inversión, que suscitaría las prevenciones de las autoridades hasta su prohibición. Después de una serie intermitente de restricciones desde 1550, el carnaval seria prohibido en Barcelona en $1641^{48}$. El argumento era "que se cometían

Lobato, I., Expressió social i ús politic de la cultura popular: festes a Barcelona (15501650), Tesis de licenciatura. Barcelona, 1986.

4Q Id. "Els perills del carnestoltes. La festa carnavalesca a la Barcelona moderna", L'Avenç. 89, enero 1986, págs. 48-52. 
ofensas contra Deu Nostre Senyor obrant la gent ab la llibertat y dissolutio, que son notoris effectes perniciosos i indecents, con vicis i llibertats indignas de persones christianes". Ya el fraile Diego Pérez en un sermón contra las máscaras publicado en 1583 en Santa María del Mar se escandalizaba asi ante el desmadre popular:

\begin{abstract}
"¿quién no vee que por la mayor parte paran las mascaras en torpezas y deshonestidades? ¿en malos pensamientos y malos deseos, y en cosas que se hazen ocultas y publicas que es verguença dezirlas? ¿Qué pasa por esas calles? ¿qué se haze por esas casas entrando y saliendo de enmascarados y enmascaradas donde se les antoja? Cuentos ay increibles y desastrosos y afrentosos: que por uno solo destos que acaeciese, o pudiese acaecer, si los hombres tuviessen honra las havian de desterrar y hundir mil estados debaxo tierra" " 9 .
\end{abstract}

Y sigue más adelante:

“En tiempo de mascaras todos los vandoleros, los vadejados, toda la hez de la tierra viene a Barcelona y anda a su plazer por las calles y casas: y hazen 10 que quieren; aunque los guarda el diabio tan astuto no consiente, antes impide, algunos particulares males, que el mundo aborrece y procura evitar, como son hurtar y matar; porque toca al que anda al mundo, que es dineros y plazer y vida: para que pueda el demonio hartar su vientre de tantas ofensas de Dios, tan grandes y tan viles, porque si en tiempo de mascaras matasen y hurtasen los enmascarados, el mundo prohibiria las mascaras. y el diablo perderia mucha ganancia..." ${ }^{50}$.

Pero el propio Pérez era consciente de la función que de válvula de escape tenía la fiesta popular:

"...que es necesario en esta Republica de Barcelona para que los hombres y las mugeres se desmelancolizen, que haya esta recreación de las máscaras. $Y$ que si no las huviese, que los hombres se melancolizarian y enfermarían» ${ }^{51}$.

En el mismo sentido se manifiesta, por cierto, Martínez de la Mata: "los estadistas aconsejan al principe tenga medios en que se divierta el pueblo, porque la melancolia no de lugar a levantar los animos a la novedad $: 52$. Y es que los poderes establecidos ante la fiesta siempre han tenido una re-

Ibidem, pág. 87.

Ibidem. pág. 88.

Ibidem, págs. 144-145

lbidem, págs. 145-146 
lación ambigua. Han necesitado de la fiesta popular en el mismo grado que la han temido.

Si las fiestas tuvieron una utilidad política como forma de evasión o distracción de problemas concretos, también es cierto que pudieron tener el carácter radicalmente contrario, de plataforma de expresiones revolucionarias. En 1633 un relato de R. Seugon promovia la celebración del carnaval en Cataluña con los siguientes argumentos:

"Aunque siempre han sido las carnestoliendas de Barcelona célebres por regocijadas en extremo grandes, por sazonadas en todo, insignes por aplaudidas de todos, y pomposas, por sus aparatos notables; con todo, este año por asistir en ella el serenissimo Infante Cardenal, ha sido mayor el regocijo, más insigne el aparato, más dilatado el aplauso, más festivo el luzimiento y el contento más singular, pues parecio que en estos dias reboçava en los pechos de los Ciudadanos Hustres, efecto del afecto con que siempre aman a sus príncipes" ${ }^{53}$.

El nacionalismo catalán no ha desaprovechado ocasión de exagerar, desde luego, esa utilización política de la fiesta. En este sentido se manifestaba A. Damians en un artículo publicado en La Renaixença en 1899:

"Era la idiosincrasia de la gent de aquella llunyana epoca, apassionada pel luxo disbauxat, las enlluhernadoras festas y'ls plahers de tota mena, o be responia al maquiavelich fi politich d'amborratxar als catalans, pera endormiscarlos y ferlos oblidar que constituhian encara un poble ab lleys, llibertats, costums y forsas propias? $" 54$.

En 1640 la fiesta popular del Corpus devendría en el suceso revolucionario más trascendente de la historia de Cataluña en la época moderna: el Corpus de Sang. Pero, en cualquier caso, ni en Cataluña ni en el conjunto de la monarquía española, la fiesta tuvo la proyección revolucionaria que sí se constata en Francia o Inglaterra. Aquí dominó la fiesta oficial con su liturgia institucionalizada y sus directrices inducidas y reglamentadas desde arriba.

Los autos de fe no fueron excepción en esta constatación, también en Cataluña. La pobreza de los autos de fe en Cataluña fue siempre cualitativa, no cuantitativa; fue testimonio de la situación económica de la sociedad catalana y de la precariedad de recursos de la propia Inquisición en

Cit. por 1. LoBATO, op. cit, pág. 159.

s.4 lbidem. 
Cataluña. Creo, en conclusión, que las limitaciones respecto al impacto festivo de los autos de fe se debieron, más que a la inhibición de la demanda social -como tantas veces se ha dicho-, a las insuficiencias de una oferta lastrada económicamente y políticamente acomplejada. Las razones de ese complejo las dejaremos para otra ocasión. 